\title{
A paradoxical severe decrease in serum HDL-cholesterol after treatment with a fibrate
}

\author{
M A Crook, J Lynas, R Wray
}

\begin{abstract}
There have been a handful of reports in the literature of a paradoxical decrease in serum high density lipoprotein (HDL)cholesterol in patients on fibrate drugs. The reason for this decline in cardioprotective HDL-cholesterol is not known and may have potential deleterious effects on the patient. This report describes a decrease in serum HDL-cholesterol in a patient on both simvastatin and bezafibrate. This patient also developed abnormal renal function, probably interstitial nephritis. In addition, the literature of fibrate induced serum HDL-cholesterol decline is reviewed and possible mechanisms for this phenomenon discussed. (F Clin Pathol 2000;53:796-797)
\end{abstract}

Keywords: fibrate; high density lipoprotein-cholesterol; renal function

There have been a small number of reports describing an anomalous decrease in serum high density lipoprotein (HDL)-cholesterol after the use of a fibrate drug. This hypoalphalipoproteinaemia has been reported with fenofibrate, ciprofibrate, and bezafibrate $\cdot{ }^{1-7}$ However, why this occurs in only a few patients and the mechanisms involved are not known. We present here a case of a paradoxical decrease in serum HDL-cholesterol in a patient on a statin/fibrate combination who had impaired renal function.

\section{Case report}

A 62 year old man presented to the cardiology clinic. He was an ex-smoker, rarely drank alcohol, and had no allergies. In his past medical history he had a coronary artery bypass graft, osteoarthritis, hiatus hernia, chronic obstructive pulmonary disease, and peripheral vascular disease. His body mass index was $32.9 \mathrm{~kg} / \mathrm{m}^{2}$ and blood pressure $120 / 80 \mathrm{~mm} \mathrm{Hg}$. His presentation serum fasting lipid values were cholesterol $8.9 \mathrm{mmol} /$ litre, triglyceride $3.45 \mathrm{mmol} /$ litre, and HDL-cholesterol $0.84 \mathrm{mmol} / \mathrm{litre}$. $\mathrm{He}$ was started on simvastatin 20 mg nocte, but his lipids remained relatively refractory at: cholesterol $9.2 \mathrm{mmol} /$ litre, triglyceride $3.73 \mathrm{mmol} /$ litre, and HDL-cholesterol $0.85 \mathrm{mmol} /$ litre. At this time, bezafibrate $400 \mathrm{mg}$ mane was added, which resulted in the following serum lipid results: cholesterol $\quad 6.7 \mathrm{mmol} /$ litre, triglyceride $3.35 \mathrm{mmol} /$ litre, and HDL-cholesterol $0.89 \mathrm{mmol} /$ litre. About two months later these were repeated and showed a serum cholesterol of $6.60 \mathrm{mmol} /$ litre, triglyceride $5.95 \mathrm{mmol} /$ litre, and HDL-cholesterol $0.13 \mathrm{mmol} /$ litre. The serum HDL-cholesterol was repeated and returned again as $0.13 \mathrm{mmol} /$ litre. It was also noted at this time that his serum creatinine was $172 \mu \mathrm{mol} /$ litre and urea $8.5 \mathrm{mmol} /$ litre. The bezafibrate was stopped and his fasting lipids returned to: cholesterol $5.9 \mathrm{mmol} /$ litre, triglyceride $1.83 \mathrm{mmol} / \mathrm{litre}$, and HDL-cholesterol $0.99 \mathrm{mmol} /$ litre. He was investigated by the renal department and a diagnosis of probable interstitial nephritis was made. About five months after stopping the bezafibrate his serum creatinine was $160 \mu \mathrm{mol} / \mathrm{litre}$ and urea $9.5 \mathrm{mmol} / \mathrm{litre}$, with fasting cholesterol $5.2 \mathrm{mmol} /$ litre, triglyceride $1.58 \mathrm{mmol} / \mathrm{litre}$, and HDL-cholesterol $1.01 \mathrm{mmol} /$ litre on simvastatin $20 \mathrm{mg}$ nocte alone.

\section{Discussion}

Although a paradoxical decrease of serum HDL-cholesterol has been described in patients treated with fibrates there is no clear explanation of the mechanism involved. This phenomenon is seen with fenofibrate, ciprofibrate, and bezafibrate.

However, the fact that (1) this effect is not necessarily reproducible in the same patient and (2) a fibrate dose dependency is sometimes observed suggests that there may be an interaction between the fibrate and some other factor. $^{1-7}$

Our case supports these earlier reports. There was no apparent HDL-cholesterol decline immediately after commencing the fibrate, although this took place about two months later. To our knowledge our case is unique in being the first report in a patient on a statin/fibrate combination.

It is also possible that the abnormal renal function was contributory to the HDL decline; particularly because fibrates can impair renal function. ${ }^{89}$ In this context, it would be interesting to know the renal function of the patients in other reports of fibrate induced hypoalphalipoproteinaemia. However, we cannot exclude an idiosyncratic interaction between these two agents. It is not obvious why there was no lipid lowering effect in response to the administration of simvastatin alone, although when the fibrate was stopped this agent was associated with an improvement; perhaps this was the result of dietary or life style changes.

It is reported that the ciprofibrate induced paradoxical decline in serum HDL-cholesterol results in an increased catabolism and decreased synthesis of apoA containing lipoproteins. ${ }^{10}$ Low serum HDL-cholesterol has been described in patients with renal impairment; indeed, the kidney is a site of 
apoA1 catabolism. ${ }^{11-14}$ Whether renal function is important in the paradoxical decline in serum HDL-cholesterol induced by fibrates in certain circumstances needs to be explored further. Interestingly, fibrates can activate peroxisome proliferator activated receptor $\alpha$ (PPAR- $\alpha$ ) with consequent affects upon apolipoproteins AI, AIII, and CIII ${ }^{15}$. This activation is known to occur in both the kidney and liver, which might be of relevance to our patient with impaired renal function.

In conclusion, we report another patient manifesting a fibrate induced lowering of serum HDL-cholesterol. Our patient is unusual in having abnormal renal function and was also on a statin at the time of the observation.

1 Chandler HA, Batchelor AJ. Ciprofibrate and lipid profile. Lancet 1994;344:128-9.

2 Capps NE Lipid profiles on fibric-acid derivatives. Lancet 1994;344:684-5.

3 McLeod AJ, Warren CJ, Armitage M. Ciprofibrate and lipid profile. Lancet 1994;344:955

4 McLeod AJ, Warren CJ, Armitage M. Abnormal lipid profiles on fibrate derivatives. Lancet 1996;347;261.

5 Collinson PO, Hjelm CJ, Canepaanson R. Paradoxical HDI density lipoprotein reduction induced by fenofibrate and ciprofibrate. Ann Clin Biochem 1996;33:159-61.
6 Oleesky DA, Mir MA. Paradoxical high density lipoprotein reduction induced by fibrate therapy. Ann Clin Biochem 1997;34:573-4

7 Murphy MJ, Packard CJ, Oreilly DS. Fibrates and HDL-cholesterol. Ann Clin Biochem 1997;34:114.

8 Lipkin GW, Thomson CRV. Severe reversible renal failure with bezafibrate. Lancet 1993;341:371.

9 Devugst O, Goffin E, Pirson Y, et al. Creatinine rise after fibrate therapy in renal graft recipients. Lancet 1993;341; 840 .

10 Beghin L, Capps N, Duhal N, et al. Metabolism of apolipoproteins $\mathrm{AI}$ and $\mathrm{AII}$ in a patient with a paradoxical reduction in high density lipoprotein due to ciprofibrate. Ann Clin Biochem 1999;36;523-5.

11 Chan MK, Varghes Z, Moorhead JF. Lipid abnormalities in uraemia, dialysis and transplantation. Kidney Int 1981;19: 625-37.

12 Rapoport J, Aviram M, Chaimovitz C, et al. Defective high density lipoprotein composition in patients on chronic haemodialysis. A possible mechanism for accelerated atherosclerosis. N Engl f Med 1978;299:1326-9.

13 Gebhardt DOE, Schmicht IM, Paul LC. The immunochemical determination of apolipoprotein A, total apolipoprotein $\mathrm{A} 1$ and free apolipoprotein $\mathrm{A} 1$ in serum of patients with chronic haemodialysis. Ann Clin Biochem 1984;21: 301-5.

14 Neary RH, Gowland E. The effect of renal failure and haemodialysis on the concentration of free apolipoprotein A1 in serum and the implications for the catabolism of high density lipoproteins. Clin Chim Acta 1988;171;239high

15 Staels B, Dallongevile J, Auwerk J, et al. Mechanisms of action of fibrates on lipid and lipoprotein metabolism. Circulation 1998;98:2088-93. 